\title{
Development of Ceria-Supported Ruthenium Catalysts Effective for Various Synthetic Reactions
}

\author{
$\operatorname{AUTHOR}(\mathrm{S})$ :
}

Wada, Kenji; Hosokawa, Saburo; Inoue, Masashi

\section{CITATION:}

Wada, Kenji ... [et al]. Development of Ceria-Supported Ruthenium Catalysts Effective for Various Synthetic Reactions. Catalysis Surveys from Asia 2011, 15(1): 1-11

\section{ISSUE DATE:}

2011-03

URL:

http://hdl.handle.net/2433/157923

\section{RIGHT:}

The final publication is available at www.springerlink.com; この論文は 出版社版でありません。引用の際には出版社版をご確認ご利用くださ $\omega_{\circ}$; This is not the published version. Please cite only the published version. 
Development of ceria-supported ruthenium catalysts effective for various synthetic reactions

Kenji Wada, Saburo Hosokawa, Masashi Inoue

M. Inoue (Corresponding author)

Department of Energy and Hydrocarbon Chemistry, Graduate School of Engineering,

Kyoto University, Katsura, Kyoto 615-8510, Japan

e-mail: inoue@scl.kyoto-u.ac.jp 


\section{Abstract}

Our recent results on organic transformations such as $\mathrm{C}-\mathrm{C}$ bond formation via the activation of stable $\mathrm{C}-\mathrm{C}$ or $\mathrm{C}-\mathrm{H}$ bonds and aerobic oxidation of alcohols catalyzed by $\mathrm{CeO}_{2}$-supported ruthenium are reviewed. A simple, recyclable heterogeneous $\mathrm{Ru} / \mathrm{CeO} \mathrm{O}_{2}$ catalyst showed excellent activity for sequential transfer-allylation/isomerization of homoallyl alcohols with aldehydes to saturated ketones via the $\mathrm{C}-\mathrm{C}$ bond activation. While homogeneous ruthenium and rhodium complex catalysts require additives and/or pressurized $\mathrm{CO}$, the reaction with $\mathrm{Ru} / \mathrm{CeO}_{2}$ smoothly proceeded in the absence of any additives. The $\mathrm{Ru} / \mathrm{CeO}_{2}$ catalyst also showed excellent activity for the addition of $\mathrm{sp}^{2}$ $\mathrm{C}-\mathrm{H}$ bonds of aromatic ketones to vinylsilanes. The $\mathrm{Ru} / \mathrm{CeO}_{2}$ catalyst also realized the chelation-assisted arylation of stable aromatic $\mathrm{C}-\mathrm{H}$ bonds with aryl chlorides. The activity of the catalyst was greatly improved by the $\mathrm{PPh}_{3}$-modification under hydrogen atmosphere prior to the reactions. The catalyst acts heterogeneously without a significant leaching of ruthenium species, indicating that the $\mathrm{Ru} / \mathrm{CeO}_{2}$ catalyst has an advantage over homogeneous catalysts from practical and environmental points of view.

The effects of chemical and physical properties of $\mathrm{CeO}_{2}$ on the activity of $\mathrm{CeO}_{2}$-supported noble metal catalysts were examined. Porous $\mathrm{CeO}_{2}$ powders were prepared by the coagulation of solvothermally synthesized colloidal ceria nanoparticles, 
and the thus-prepared $\mathrm{CeO}_{2}$ powders showed an oxygen migration ability far superior to the $\mathrm{CeO}_{2}$ samples prepared by the usual precipitation method. The ruthenium catalysts supported on the former $\mathrm{CeO}_{2}$ powders showed a high activity for the aerobic oxidation of benzyl alcohol. The effects of the pore structure of $\mathrm{CeO}_{2}$ powders on the activity of the $\mathrm{Ru} / \mathrm{CeO}_{2}$ catalysts are also discussed.

Keywords: Ruthenium - Ceria - Heterogeneous catalysis $-\mathrm{C}-\mathrm{H}$ bond activation $-\mathrm{C}-\mathrm{C}$ bond formation - Aerobic oxidation - Benzyl alcohol

\section{Introduction}

Of the rare earth oxides, ceria is most widely used as catalysts [1-6], polishing materials, gas sensors [7], ultraviolet absorbents [8], oxygen ion conductors in solid oxide fuel cells [9-10], and so on. Characteristic interactions of $\mathrm{CeO}_{2}$ with supported noble metal species such as stabilization of the highly dispersed state of noble metal species play important roles in catalysis $[1,3,4,6]$. Such characteristics lead to the improved performance of noble-metal/ $\mathrm{CeO}_{2}$ catalysts for automobile exhaust conversion [11-13] and many other reactions; for example, $\mathrm{Rh} / \mathrm{CeO}_{2}$ for methane partial oxidation [14] and 
$\mathrm{N}_{2} \mathrm{O}$ decomposition [15], $\mathrm{Pt} / \mathrm{CeO}_{2}$ for $\mathrm{CO}$ oxidation [16] and hydrogenation [17], and $\mathrm{Pd} / \mathrm{CeO}_{2}$ for methanol decomposition [18]. Recently, $\mathrm{CeO}_{2}$-supported gold catalysts were adopted in organic transformations such as homocoupling of phenylboronic acids [19] and hydrosilylation of aldehydes, ketones, alkenes, imines, and alkynes [20].

Among $\mathrm{CeO}_{2}$-supported catalysts, the ruthenium catalyst has attracted much attention because of the formation of characteristic surface ruthenium species such as highly-dispersed pentacoordinated ruthenium oxo species [21]. Remarkable activities of the $\mathrm{Ru} / \mathrm{CeO}_{2}$ catalysts have been reported for liquid-phase oxidation of alcohols or aldehydes [22-24], wet oxidation of organic pollutants in waste water [25,26], ammonia synthesis [27], $\mathrm{N}_{2} \mathrm{O}$ decomposition [21], complete oxidation of ethyl acetate and propylene [28,29], and other reactions. Recently, $\mathrm{Ce}_{1-\mathrm{x}} \mathrm{Ru}_{\mathrm{x}} \mathrm{O}_{2-\delta}$ solid solution was reported as a new oxygen storage material [30]. To further improve the catalytic activity of $\mathrm{Ru} / \mathrm{CeO}_{2}$, systematic investigations on control of their pore structures and surface properties are indispensable. In addition, the application of solid catalysts such as $\mathrm{Ru} / \mathrm{CeO}_{2}$ to various organic transformations as recyclable heterogeneous catalysts is highly desired from practical and environmental points of view.

In this account, we first describe our recent achievements of the $\mathrm{Ru} / \mathrm{CeO}_{2}$-catalyzed $\mathrm{C}-\mathrm{C}$ bond formations via the selective activation of stable $\mathrm{C}-\mathrm{C}$ and 
$\mathrm{C}-\mathrm{H}$ bonds. These reactions have significantly broadened the range of organic reactions for which the environmentally benign solid catalysts are applicable. In the latter section, we focus on the contribution of the oxygen migration ability of the $\mathrm{CeO}_{2}$ support on the catalytic activity of $\mathrm{Ru} / \mathrm{CeO}_{2}$. In addition, systematic control of the pore structure of the $\mathrm{Ru} / \mathrm{CeO}_{2}$ catalysts and the $\mathrm{CeO}_{2}$ supports is described.

\section{2. $\mathrm{Ru} / \mathrm{CeO}_{2}$-catalyzed organic transformations via stable $\mathrm{C}-\mathrm{H}$ or $\mathrm{C}-\mathrm{C}$ bond} activation

Homogeneous ruthenium complex catalysts have been extensively investigated because they provide powerful tools in modern organic synthesis [31]. In particular, the asymmetric hydrogenation developed by Noyori et al. [32] and the alkene metathesis developed by Grubbs et al. [33] are the most prominent achievements realized by ruthenium complex catalysts. In addition, carbon-carbon bond formations via the activation of stable $\mathrm{C}-\mathrm{H}$ bonds $[34,35]$ and unstrained $\mathrm{C}-\mathrm{C}$ bonds $[36,37]$ have been achieved by the use of low-valent ruthenium complex catalysts. Despite the excellent activities and selectivities, these homogeneous catalysts have significant drawbacks for practical uses such as the high cost of catalyst production, high sensitivity towards air 
and moisture, problems in the catalyst separation, and so on. The use of heterogeneous catalysts is an effective way to overcome these disadvantages. Among the heterogeneous catalysts, oxide-supported catalysts are particularly advantageous because of their low production costs and high thermal and/or chemical stabilities. In most cases, solid catalysts are readily removed from the reaction mixture by simple filtration without leaching of metallic species and can be recycled $[38,39]$. Therefore, we focused our efforts on the quest for solid oxide-supported ruthenium catalysts that show activities superior to those of homogeneous catalysts for the carbon-carbon bond formation via $\mathrm{C}-\mathrm{H}$ or $\mathrm{C}-\mathrm{C}$ bond activation.

Our first target is the transfer-allylation from tertiary homoallylic alcohols to aldehydes via selective cleavage of non-strained carbon-carbon bonds. The reaction of this type was first developed by Kondo et al. and several ruthenium-phosphine complexes were found to be effective [40]. Afterwards, Oshima and coworkers reported rhodium complex-catalyzed reactions [41]. For both of the catalysts, however, phosphorous additives, inorganic bases, an excess amount of allylic alcohols, and/or pressurized carbon monoxide are required.

After our extensive survey of oxide-supported catalysts, we found that $\mathrm{CeO}_{2}$-supported ruthenium catalyst shows an excellent activity for this reaction [42]. As 
shown in Table 1, the reaction of homoallylic alcohol (1a) with benzaldehyde (2a) at $170{ }^{\circ} \mathrm{C}$ in the presence of a catalytic amount of $\mathrm{Ru}(2.0 \mathrm{wt} \%) / \mathrm{CeO}_{2}$, which was prepared by the usual impregnation method by using a THF solution of $\mathrm{Ru}_{3}(\mathrm{CO})_{12}$, gave the desired product $\mathbf{4 a}$ in $69 \%$ yield together with acetophenone (3). Ruthenium catalysts supported on $\mathrm{SiO}_{2}, \mathrm{Al}_{2} \mathrm{O}_{3}, \mathrm{TiO}_{2}$, or $\mathrm{MgO}$ did not show any activity at all, indicating that the combination of ruthenium and $\mathrm{CeO}_{2}$ is essential for the generation of catalytically active species. The reaction in the presence of acidic $\mathrm{TiO}_{2}$ or $\mathrm{Ru} / \mathrm{TiO}{ }_{2}$ did not give $4 \mathbf{a}$ but gave an indene derivative (5a) via intramolecular Friedel-Crafts reaction of 1a, suggesting that the present transfer-allylation does not proceed via the carbonyl-ene-type pathway catalyzed by Lewis acids [43]. The $\mathrm{Ru} / \mathrm{CeO}_{2}$ catalyst was recyclable at least three times without a loss in the activity after calcination at $400{ }^{\circ} \mathrm{C}$ for $30 \mathrm{~min}$, and the ICP-AES analysis revealed that leaching of the ruthenium species from the solid catalysts during the reaction shown in entry 2 of Table 1 was 0.0014 mmol.

(Table 1)

(structure of 5a) 
The reaction of 1a with a variety of aromatic aldehydes smoothly proceeded to give the desired ketones in moderate to high yields (Table 2). In the reaction for $2 \mathrm{~h}$ or less, the major product was a homoallylic alcohol, $6 \mathbf{a}(\mathrm{Ar}=\mathrm{Ph})$. This indicates that the present reaction proceeds via transfer-allylation to form intermediates (6), followed by the isomerization of $\mathbf{6}$ to ketones, 4 .

(Table 2)

(Structure of 6)

The initial step of these reactions might consist of the oxidative addition of an $\mathrm{OH}$ group of $\mathbf{1}$ to an active ruthenium species and the $\beta$-allyl elimination to give $\mathbf{3}$ and an (allyl)ruthenium intermediate, which would react with an aldehyde to give the homoallyl alcohol (6). Based on the spectroscopic study of the catalysts, low-valent ruthenium species on the surface of $\mathrm{CeO}_{2}$ generated in situ were considered to be catalytically active. In the XPS study, the Ru 3d5/2 binding energy in the used catalyst was found to be lower than that in the fresh catalyst, indicating that ruthenium(IV) species was reduced during the reaction.

These results provide the first example of allyl transfer reactions via the 
selective cleavage of an unstrained carbon-carbon bond promoted by solid ruthenium catalysts. Note that no additives such as phosphines, amines, or $\mathrm{CO}$ were required and the catalyst was recyclable.

Following the success of our first attempt, we speculated that $\mathrm{Ru} / \mathrm{CeO}_{2}$ has the potential to be a good alternative to homogeneous ruthenium complex catalysts. Therefore, we examined the catalytic activity of $\mathrm{Ru} / \mathrm{CeO}_{2}$ towards the addition of aromatic $\mathrm{C}-\mathrm{H}$ bonds to vinylsilanes [44]. This reaction is one of the most important organic transformations catalyzed by the homogeneous ruthenium complexes [34] and there has been no previous report on the reactions facilitated by solid catalysts. The reaction of $\alpha$-tetralone (7a) with triethoxyvinylsilane (8a) in the presence of $\mathrm{Ru} / \mathrm{CeO}_{2}$ and $\mathrm{PPh}_{3}(0.10 \mathrm{mmol}, 4$ equivalents to $\mathrm{Ru}$ species $)$ at $170{ }^{\circ} \mathrm{C}$ for $24 \mathrm{~h}$ afforded the desired product 9a in 99\% yield with complete regioselectivity (Table 3). Among the phosphorous additives examined, only $\mathrm{PPh}_{3}$ and $\mathrm{P}\left(p-\mathrm{F}-\mathrm{C}_{6} \mathrm{H}_{4}\right)_{3}$ were effective, and in the absence of these phosphines, the reaction did not proceed. $\mathrm{ZrO}_{2}$-supported ruthenium catalyst showed an activity comparable to that of $\mathrm{Ru} / \mathrm{CeO}_{2}$, whereas $\mathrm{SiO}_{2^{-}}, \mathrm{Al}_{2} \mathrm{O}_{3^{-}}$, $\mathrm{TiO}_{2^{-}}$, or $\mathrm{MgO}$-supported ruthenium catalysts did not show any activity even in the presence of $\mathrm{PPh}_{3}$. 
(Table 3)

Various aromatic ketones bearing either electron donating or withdrawing substituents were applicable as well as heteroaromatic ketones, and the desired alkylated products were produced in the yields of 67 to $96 \%$ (at $170{ }^{\circ} \mathrm{C}$ for $24 \mathrm{~h}$ ) in a completely regioselective manner (Table 4). On the other hand, the scope of alkenes was limited. At present, only $8 \mathbf{a}$ and dimethylethoxyvinylsilane $(\mathbf{8 b})$ have been found to be applicable, and the reaction of $\mathbf{7 a}$ with other alkenes resulted in very low yields of the desired adducts. Hot filtration of the solid catalyst during the reaction almost completely suppressed further progress of the reaction, indicating that the reaction requires the presence of the solid catalyst, and the leaching of ruthenium species from the catalyst to the reaction mixture was $0.00075 \mathrm{mmol}$ (entry 3 in Table 3). From a practical point of view, it is highly desired that the reaction could be conducted on a large scale without a solvent. The reaction of $35 \mathrm{mmol}$ of $7 \mathbf{a}$ with $80 \mathrm{mmol}$ of $8 \mathbf{a}$ afforded $9 \mathbf{a}$ with a high TON of 837, which is slightly lower than the highest value (1125) reported for homogeneous ruthenium catalysts [35].

(Table 4) 
We deduced that a high reaction temperature, $170{ }^{\circ} \mathrm{C}$, would be required for in situ generation of catalytically active species, presumably reduced surface ruthenium phosphine complexes. Therefore, the effects of reductive pretreatment in the presence of phosphines were examined. The treatment of $\mathrm{Ru} / \mathrm{CeO}_{2}$ at $100{ }^{\circ} \mathrm{C}$ for $20 \mathrm{~min}$ in the presence of $\mathrm{PPh}_{3}$ under $\mathrm{H}_{2}$ (Scheme 1) gave a $\mathrm{PPh}_{3}$-modified $\mathrm{Ru} / \mathrm{CeO}_{2}$ catalyst $\left(x \mathrm{PPh}_{3}-\mathrm{Ru} / \mathrm{CeO}_{2}, x=\right.$ molar ratio of $\left.\mathrm{PPh}_{3} / \mathrm{Ru}\right)$. The thus-modified catalyst showed an activity surprisingly higher than that of the unmodified catalysts and gave 9a in $99 \%$ yield at a significantly lower temperature, $140{ }^{\circ} \mathrm{C}$ (bath temperature, under vigorous toluene reflux), within 90 min. Note that the catalyst reduced in the absence of $\mathrm{PPh}_{3}$ did not show catalytic activity at all, even for the reactions performed in the presence of $\mathrm{PPh}_{3}$.

(Scheme 1)

As shown above, the addition of stable aromatic $\mathrm{C}-\mathrm{H}$ bonds to vinylsilanes was achieved by $\mathrm{Ru} / \mathrm{CeO}_{2}$ or $\mathrm{Ru} / \mathrm{ZrO}_{2}$ catalysts with a small amount of $\mathrm{PPh}_{3}$ for the first time, and the reaction smoothly proceeded even under solvent-free conditions. The 
reductive pretreatment of the $\mathrm{Ru} / \mathrm{CeO}_{2}$ in the presence of $\mathrm{PPh}_{3}$ was found to increase the catalytic activity markedly.

On the other hand, the nitrogen-directed arylation of stable aromatic $\mathrm{C}-\mathrm{H}$ bonds with aryl halides provides a useful pathway for preparing unsymmetrical biaryls with high atomic efficiency [45-47], and several low-valent ruthenium complex catalysts such as $\left[\mathrm{RuCl}_{2}\left(\mathrm{C}_{6} \mathrm{H}_{6}\right)\right]_{2}$ with $\mathrm{PPh}_{3}[45]$ or $\left[\mathrm{RuCl}_{2}(p \text {-cymene })\right]_{2}$ together with a special kind of phosphorous ligands [46] were reported to be effective for this reaction. However, no previous examples of oxide-supported catalysts effective for reactions of this type have been reported so far.

Recently, we found that $\mathrm{Ru} / \mathrm{CeO}_{2}$ or $\mathrm{Ru} / \mathrm{ZrO}_{2}$ catalysts are quite effective for the chelation-assisted direct arylation of aromatic $\mathrm{C}-\mathrm{H}$ bonds [48]. In the absence of phosphorous additives, the $\mathrm{Ru} / \mathrm{CeO}_{2}$-catalyzed reaction of benzo[h]quinoline (10a) with chlorobenzene (11a) at $170{ }^{\circ} \mathrm{C}$ for $18 \mathrm{~h}$ regioselectively afforded an arylated product (12a) in $89 \%$ yield (eq. 1). Again, ruthenium catalysts supported on oxides other than $\mathrm{CeO}_{2}$ or $\mathrm{ZrO}_{2}$ did not show any activities. The reaction with methyl-, fluoro-, and trifluoromethyl-substituted chlorobenzenes gave biaryls in moderate to high yields, while chloroarenes with coordinating substituents such as 1-chloro-4-methoxybenzene (11g) could not be used (Table 5). In the presence of a catalytic amount of $\mathrm{PPh}_{3}$, the 
reaction of $10 \mathrm{a}$ with $\mathbf{1 1 g}$ efficiently proceeded, and the addition of $\mathrm{PPh}_{3}$ significantly broadened the scope of the substrates. However, relatively high reaction temperature was still essential.

(eq. 1)

(Table 5)

Therefore, the effects of $\mathrm{PPh}_{3}$-modification of $\mathrm{Ru} / \mathrm{CeO}_{2}$ were examined (Table 6). $3 \mathrm{PPh}_{3}-\mathrm{Ru} / \mathrm{CeO}_{2}$ showed enhanced activity, and the reaction of $\mathbf{1 0 a}$ with chlorobenzene (11a) completed within $6 \mathrm{~h}$ at $140{ }^{\circ} \mathrm{C}$ while the reaction with bromobenzene $(\mathbf{1 1 h})$ completed within $2 \mathrm{~h}$ at $120{ }^{\circ} \mathrm{C}$. Again, the catalyst reduced in the absence of $\mathrm{PPh}_{3}$ did not show catalytic activity at all, even for the reactions performed in the presence of $\mathrm{PPh}_{3}$. A variety of chloroarenes were applicable for the reaction catalyzed by $\mathrm{PPh}_{3}$-modified $\mathrm{Ru} / \mathrm{CeO}_{2}$. The $\mathrm{PPh}_{3}$-modification of $\mathrm{Ru} / \mathrm{CeO}_{2}$ catalyst further broadened the scope of applicable haloarenes. In addition to 10a, other directed $\mathrm{C}-\mathrm{H}$ activation substrates could be applied (Table 7).

(Table 6) 
(Table 7)

The $\mathrm{PPh}_{3}$-modified catalysts were recyclable at least three times without a loss

of activity for the reaction of $\mathbf{1 0 a}$ and $\mathbf{1 1 a}$ at $140{ }^{\circ} \mathrm{C}$ (Table 6), and leaching of ruthenium species into the reaction mixture was $0.00065 \mathrm{mmol}$. Hot filtration of solid catalysts completely stopped further progress of the reaction. These results indicate that $\mathrm{Ru} / \mathrm{CeO}_{2}$ and $\mathrm{Ru} / \mathrm{ZrO}_{2}$ act as environmentally-benign, recyclable heterogeneous catalysts effective for direct $\mathrm{C}-\mathrm{H}$ arylation with a wide range of aryl chlorides.

For the three reactions described above, only $\mathrm{CeO}_{2}$ or $\mathrm{ZrO}_{2}$-supported ruthenium catalysts showed activity. Although the exact reason is not clear yet, $\mathrm{Ru} / \mathrm{CeO}_{2}$ and $\mathrm{Ru} / \mathrm{ZrO}_{2}$ showed several characteristic features in the spectroscopic study. The XRD study showed that the crystallites of $\mathrm{RuO}_{2}$ were present on the surface of $\mathrm{SiO}_{2}$, $\mathrm{Al}_{2} \mathrm{O}_{3^{-}}$, and $\mathrm{MgO}$-supported catalysts. On the other hand, the ruthenium catalysts supported on $\mathrm{CeO}_{2}$ or $\mathrm{ZrO}_{2}$ did not exhibit the XRD peaks due to ruthenium phases, indicating ruthenium species are highly dispersed. (XRD patterns are shown in the supporting information of ref. [48]). In the diffuse reflectance infrared Fourier transform (DRIFT) spectra of $\mathrm{Ru} / \mathrm{CeO}_{2}$, a strong band was recognized at around $975 \mathrm{~cm}^{-1}$, which is assignable to ruthenium(IV) oxo species [21]. This band disappeared after the 
reaction and regenerated by the re-calcination $[42,44,48]$. Although the distinct band due to ruthenium oxo species was not recognized on $\mathrm{Ru} / \mathrm{ZrO}_{2}$ in the present studies, the formation of reactive ruthenium-oxygen species has been proposed for the $\mathrm{ZrO}_{2}$-supported ruthenium catalyst $[29,49]$. On the other hand, there were no signs of oxo species for ruthenium catalysts supported on the other oxides $[42,44,48]$. In the temperature-programmed reduction with hydrogen $\left(\mathrm{H}_{2}-\mathrm{TPR}\right)$, the fresh $\mathrm{Ru} / \mathrm{CeO}_{2}$ and $\mathrm{Ru} / \mathrm{ZrO}_{2}$ catalysts showed reduction peaks at below $60{ }^{\circ} \mathrm{C}$, indicating that surface ruthenium species on $\mathrm{CeO}_{2}$ and $\mathrm{ZrO}_{2}$ are easily reduced. On the other hand, the reduction of ruthenium species on the other supports occurred at above $70{ }^{\circ} \mathrm{C}$ [48]. Based on these data, we deduce, at the present stage, that ruthenium(IV) oxo species is a good precursor of catalytically active species, and these active species would be generated in situ by the reduction at the beginning of catalytic runs or $\mathrm{PPh}_{3}$-modification prior to the reaction. The $\mathrm{Ru} / \mathrm{CeO}_{2}$-catalyzed $\mathrm{C}-\mathrm{H}$ alkylation and arylation are considered to proceed via the chelation-assisted regioselective activation of the aromatic $\mathrm{C}-\mathrm{H}$ bond, which have been proposed for the reactions catalyzed by ruthenium complexes [34,35,45-47], since the regioselectivities of the present reactions are identical to those catalyzed by the ruthenium complexes. Detailed studies on the structure of ruthenium species supported on $\mathrm{CeO}_{2}$ or $\mathrm{ZrO}_{2}$ as well as the nature of 
catalytically active species of $\mathrm{PPh}_{3}$-modified $\mathrm{Ru} / \mathrm{CeO}_{2}$ and detailed reaction mechanisms are now in progress.

\section{Aerobic oxidation of benzyl alcohol on $\mathrm{Ru} / \mathrm{CeO}_{2}$ prepared from ceria}

\section{nanoparticles}

The $\mathrm{Ru} / \mathrm{CeO}_{2}$ catalyst has high activities for various oxidative reactions such as wet oxidation and combustion of organic compounds, as indicated in the introduction section [21-30]. In this chapter, the performances of the $\mathrm{Ru} / \mathrm{CeO}_{2}$ catalysts prepared from various $\mathrm{CeO}_{2}$ powders were compared in terms of the activity for aerobic oxidation of benzyl alcohol as a model reaction. Note that Vocanson et al. reported that $\mathrm{Ru} / \mathrm{CeO}_{2}$ catalyst is effective for the oxidation of various alcohols [22].

Table 8 compares the properties and activities of two representative $\mathrm{Ru} / \mathrm{CeO}_{2}$ catalysts [50]. One catalyst, $\mathrm{Ru} / \mathrm{CeO}_{2}-\mathrm{A}$, was prepared by the addition of a $3 \mathrm{M} \mathrm{NaOH}$ solution to an aqueous solution $(500 \mathrm{~mL})$ containing ceria colloids (in $100 \mathrm{~mL}$ of 2-methoxyethanol; $\left.\mathrm{CeO}_{2}, 3-4 \mathrm{~g}\right), \mathrm{RuCl}_{3} \bullet n \mathrm{H}_{2} \mathrm{O}$, and formalin $(10 \mathrm{~mL})$ until the $\mathrm{pH}$ of the solution became 11 , followed by calcination at $500{ }^{\circ} \mathrm{C}$ for $3 \mathrm{~h}$ in air. Another catalyst 
designated as $\mathrm{Ru} / \mathrm{CeO}_{2}-\mathrm{B}$ was prepared using an aqueous solution $(500 \mathrm{~mL})$ containing $\mathrm{Ce}\left(\mathrm{NO}_{3}\right)_{3} \cdot 6 \mathrm{H}_{2} \mathrm{O}(0.030 \mathrm{~mol})$ in place of the ceria colloidal solution for the recipe of $\mathrm{Ru} / \mathrm{CeO}_{2}-\mathrm{A}$. Furthermore, two pure $\mathrm{CeO}_{2}$ powders were prepared: $\mathrm{CeO}_{2}-\mathrm{A}$ by the coagulation of ceria colloidal nanoparticles with a $3 \mathrm{M}$ aqueous $\mathrm{NaOH}$ solution followed by washing and calcination at $400{ }^{\circ} \mathrm{C}$ for $3 \mathrm{~h}$, and $\mathrm{CeO}_{2}-\mathrm{B}$ by the usual precipitation method using an aqueous solution of $\mathrm{Ce}\left(\mathrm{NO}_{3}\right)_{3} \cdot 6 \mathrm{H}_{2} \mathrm{O}$ and a $3 \mathrm{M} \mathrm{NaOH}$ solution.

As shown in Table $8, \mathrm{Ru} / \mathrm{CeO}_{2}$-A possessed a surface area slightly smaller than that of $\mathrm{Ru} / \mathrm{CeO}_{2}-\mathrm{B}$; however, $\mathrm{Ru} / \mathrm{CeO}_{2}-\mathrm{A}$ exhibited higher catalytic activity for the oxidation of benzyl alcohol, clearly indicating that surface area is not an important factor governing the activities. The XRD analysis of both the catalysts gave similar patterns in which only the peaks due to $\mathrm{CeO}_{2}$ were recognized, suggesting that ruthenium species on both of the catalysts were well-dispersed.

(Table 8)

The $\mathrm{H}_{2}$-TPR profiles of $\mathrm{Ru} / \mathrm{CeO}_{2}-\mathrm{B}$, a physical mixture of $\mathrm{RuO}_{2}-\alpha-\mathrm{Al}_{2} \mathrm{O}_{3}$, and $\mathrm{CeO}_{2}-\mathrm{B}$ are shown in Figure 1. The TPR profile of $\mathrm{CeO}_{2}-\mathrm{B}$ showed two reduction peaks, 
one at $300-500{ }^{\circ} \mathrm{C}$ and the other at a higher temperature $>500{ }^{\circ} \mathrm{C}$. The former peak has been assigned to the reduction of the surface $\mathrm{Ce}^{\mathrm{IV}}$ species, and the latter peak has been ascribed to the reduction of lattice $\mathrm{Ce}^{\mathrm{IV}}$ species [11]. On the other hand, ruthenium species on $\mathrm{Ru} / \mathrm{CeO}_{2}-\mathrm{B}$ were reduced at a temperature lower than that required for the reduction of $\mathrm{RuO}_{2}$, indicating the formation of highly dispersed surface $\mathrm{Ru}=\mathrm{O}$ species on $\mathrm{Ru} / \mathrm{CeO}_{2}-\mathrm{B}[21,51]$. Note that in the profile of $\mathrm{Ru} / \mathrm{CeO}_{2}-\mathrm{B}$, the low-temperature reduction peak of $\mathrm{CeO}_{2}$ disappeared, and the amount of $\mathrm{H}_{2}$ consumed by $\mathrm{Ru} / \mathrm{CeO}_{2}-\mathrm{B}$ at $<100{ }^{\circ} \mathrm{C}$ was much larger than the theoretical value $\left(0.40 \mathrm{mmol} \mathrm{g}^{-1}\right)$ calculated on the basis of the following equation assuming that all the ruthenium species are in the form of $\mathrm{RuO}_{2}$ :

$$
\mathrm{RuO}_{2}+2 \mathrm{H}_{2} \rightarrow \mathrm{Ru}^{0}+2 \mathrm{H}_{2} \mathrm{O}
$$

The $\mathrm{H}_{2}$ consumption by $\mathrm{Ru} / \mathrm{CeO}_{2}-\mathrm{B}\left(0.72 \mathrm{mmol} \mathrm{g}{ }^{-1}\right.$, Table 8$)$ was almost equal to the sum of $\mathrm{H}_{2}$ uptakes of $\mathrm{RuO}_{2}-\alpha$-alumina $\left(0.27 \mathrm{mmol} \mathrm{g}{ }^{-1}\right)$ and $\mathrm{CeO}_{2}-\mathrm{B}$ at the lower temperature range $\left(0.41 \mathrm{mmol} \mathrm{g} \mathrm{g}^{-1}\right)$. These results indicate that the ruthenium species accelerate the reduction of surface $\mathrm{Ce}^{\mathrm{IV}}$, probably due to migration of surface oxygen species from $\mathrm{CeO}_{2}$ to ruthenium species.

(Figure 1) 
Based on the above discussion, the ability of surface oxygen migration of $\mathrm{CeO}_{2}$ supports is expected to contribute to the oxidation of benzyl alcohol. Therefore, the redox properties of $\mathrm{CeO}_{2}-\mathrm{A}$ and $-\mathrm{B}$ were compared by the repeated TPR analyses (Figure 2 and Table 9). The sample was subjected to the TPR study up to $500{ }^{\circ} \mathrm{C}$, then oxidized with $\mathrm{O}_{2}$ at $300{ }^{\circ} \mathrm{C}$, and again subjected to the TPR procedure up to $950{ }^{\circ} \mathrm{C}$. As judged from the low temperature peak areas of $1^{\text {st }}$ and $2^{\text {nd }}$ TPR measurements, $81 \%$ of the original oxidized-surface of $\mathrm{CeO}_{2}$-A was recovered during the re-oxidation process, while only $61 \%$ was recovered for $\mathrm{CeO}_{2}-\mathrm{B}$. These results clearly indicate that the surface of $\mathrm{CeO}_{2}-\mathrm{A}$, a single component $\mathrm{CeO}_{2}$ sample prepared by the coagulation of the ceria colloidal nanoparticles, was more easily reduced and re-oxidized than the $\mathrm{CeO}_{2}$ sample prepared by the precipitation method from $\mathrm{Ce}\left(\mathrm{NO}_{3}\right)_{3}$. The higher activity of $\mathrm{Ru} / \mathrm{CeO}_{2}-\mathrm{A}$ is brought about by the inherent high surface oxygen mobility of the $\mathrm{CeO}_{2}$ support itself.

(Figure 2)

(Table 9) 


\section{Pore structure control of ceria nanoparticles}

Nanoparticles of metal oxides generally show characteristic features and are expected to be excellent supports for highly active catalysts. So far, several preparation methods of ceria nanoparticles have been developed [52-54]. One of the authors reported that the solvothermal reaction of $\mathrm{Ce}$ metal in 2-methoxyethanol yielded a transparent colloidal solution containing ceria nanoparticles with a particle size of $c a .2 \mathrm{~nm}[55,56]$.

In this chapter, the pore-structure control of $\mathrm{CeO}_{2}$ prepared by coagulation of solvothermally synthesized ceria colloidal nanoparticles is described. High surface energy of colloidal nanoparticles induced a strong tendency to coagulate by the addition of alkaline solutions, and subsequent calcination produced $\mathrm{CeO}_{2}$ powders with microor meso-pores originating from the voids between primary ceria nanoparticles [57]. The pore structure of $\mathrm{CeO}_{2}$ powders was partly controlled by the selection of alkaline solutions [58]. Table 10 compares crystallite sizes and pore structures of various $\mathrm{CeO}_{2}$ powders, which were coagulated by the addition of aqueous solutions of various bases $\left(1 \mathrm{M}, 200 \mathrm{~mL}\right.$ ) to ceria colloidal solutions, followed by calcination at $300{ }^{\circ} \mathrm{C}$ for $3 \mathrm{~h}$. Whereas the crystallite sizes of all the $\mathrm{CeO}_{2}$ powders after the coagulation and calcination were in the range of $4-5 \mathrm{~nm}$, their pore structures were significantly affected 
by the coagulants. In particular, the $\mathrm{CeO}_{2}$ powders prepared by using $\mathrm{NaOH}$ and $\left(\mathrm{NH}_{4}\right)_{2} \mathrm{CO}_{3}$ had large surface areas over $120 \mathrm{~m}^{2} \mathrm{~g}^{-1}$. The nitrogen adsorption/desorption isotherms of the $\mathrm{CeO}_{2}$ powders are shown in Figure 3. The $\mathrm{CeO}_{2}$ powders prepared using $\mathrm{Na}_{2} \mathrm{CO}_{3}$ and $\mathrm{NH}_{4} \mathrm{OH}$ showed typical type-I isotherms characteristic of microporous materials. The powders prepared using $\mathrm{NaOH}$ and $\mathrm{NH}_{4} \mathrm{HCO}_{3}$ showed E-type hysteresis loops based on the de Boer classification, which were responsible for ink-bottle or tubular pores formed between primary particles. For the powders coagulated with $\left(\mathrm{NH}_{4}\right)_{2} \mathrm{CO}_{3}$ and $\mathrm{NaHCO}_{3}$, large amounts of nitrogen were adsorbed at the high $P / P_{0}$ range over 0.8 , indicating the formation of macropores. The XRD and TG analyses of powders coagulated with $\left(\mathrm{NH}_{4}\right)_{2} \mathrm{CO}_{3}$ and $\mathrm{NaHCO}_{3}$ before calcination indicate the presence of a small amount of crystalline $\mathrm{Ce}_{2}\left(\mathrm{CO}_{3}\right)_{3} \cdot 8 \mathrm{H}_{2} \mathrm{O}$ formed from atmospheric $\mathrm{CO}_{2}$ and cerium ions remaining in the solution after the solvothermal reaction. Evolution of $\mathrm{CO}_{2}$ gas from $\mathrm{Ce}_{2}\left(\mathrm{CO}_{3}\right) \bullet 8 \mathrm{H}_{2} \mathrm{O}$ during calcination is one reason for the formation of macropores.

(Table 10)

(Figure 3) 
The effects of the pore-structure of $\mathrm{CeO}_{2}$ powders on the catalytic activity of $\mathrm{Ru} / \mathrm{CeO}_{2}$ for the liquid-phase aerobic oxidation of benzyl alcohol were examined [58] and Table 11 shows the results. The $\mathrm{Ru} / \mathrm{CeO}_{2}$ catalysts were prepared as follows; the prescribed amount of $\mathrm{RuCl}_{3} \bullet n \mathrm{H}_{2} \mathrm{O}$ was dissolved in a suspension of $\mathrm{CeO}_{2}$ powders in water. After the addition of $5 \mathrm{~mL}$ of a $37 \%$ aqueous formaldehyde solution, the suspension was heated at $80{ }^{\circ} \mathrm{C}$ for $0.5 \mathrm{~h}$ and then a $3 \mathrm{M} \mathrm{NaOH}$ solution was added until the $\mathrm{pH}$ of the suspension became $c a$. 11 . The precipitate was dried at $80{ }^{\circ} \mathrm{C}$ and calcined at $500{ }^{\circ} \mathrm{C}$ for $3 \mathrm{~h}$. The catalysts prepared using the $\mathrm{CeO}_{2}$ powders with relatively large meso- and macro-pore surface area exhibited higher activities to give benzaldehyde in the yields of about 58\% (entries 4-6). No other products were detected in GC analysis. A control experiment showed ca. $10 \%$ benzaldehyde was adsorbed on the catalyst.

The XRD patterns of poorly active $\mathrm{Ru} / \mathrm{CeO}_{2}$ catalysts prepared using $\mathrm{NaOH}$, $\mathrm{NH}_{4} \mathrm{OH}$, and $\mathrm{Na}_{2} \mathrm{CO}_{3}$ showed peaks due to $\mathrm{RuO}_{2}$ crystallites. The $\mathrm{H}_{2}-\mathrm{TPR}$ study also indicates marked effects of coagulants on the state of surface ruthenium species of $\mathrm{Ru} / \mathrm{CeO}_{2}$. The highly active catalysts showed a sharp peak at $\sim 75{ }^{\circ} \mathrm{C}$ due to ruthenium(IV) oxo species [21,51]. On the other hand, the poorly active catalysts showed two peaks at $75{ }^{\circ} \mathrm{C}$ and $90{ }^{\circ} \mathrm{C}$; the latter peak is due to crystalline $\mathrm{RuO}_{2}$. These results indicate that the $\mathrm{Ru} / \mathrm{CeO}_{2}$ catalysts prepared using $\mathrm{CeO}_{2}$ powders with large 
surface areas in meso- and macro-pore regions generally possess highly dispersed surface ruthenium(IV) oxo species and showed excellent catalytic activities.

(Table 11)

The pore structure of $\mathrm{CeO}_{2}$ powders derived from colloidal nanoparticles can also be controlled by the concentration of the $\mathrm{NaOH}$ coagulant [59]. High concentration of the $\mathrm{NaOH}$ solution gave the $\mathrm{CeO}_{2}$ coagulate having well-developed mesopores, while BET surface areas were not affected by $\mathrm{NaOH}$ concentration. The $10 \mathrm{M} \mathrm{NaOH}$ solution partially dissolved ceria nanoparticles because of their high surface energy. It is known that ceria dissolves in acidic solutions in the presence of hydrogen peroxide, and hardly dissolves in alkaline solutions [60]. Actually, the pore structure of the $\mathrm{CeO}_{2}$ sample prepared by a conventional precipitation method using a $\mathrm{Ce}\left(\mathrm{NO}_{3}\right)_{3}$ solution is not affected by the concentration of the $\mathrm{NaOH}$ solution. Therefore, characteristic pore structure caused by the coagulation of ceria colloidal particles with a highly concentrated $\mathrm{NaOH}$ solution was thought to be due to the nature of the ceria colloidal nanoparticles. As expected, the $\mathrm{Ru} / \mathrm{CeO}_{2}$ catalyst prepared by coagulation of the ceria nanoparticles with the $10 \mathrm{M} \mathrm{NaOH}$ solution showed higher activity and higher yield 
(73\%) than the catalyst prepared using $1 \mathrm{M} \mathrm{NaOH}(65 \%)$.

(Table 12)

(Figure 4)

\section{Concluding remarks}

We have demonstrated the excellent activities of the $\mathrm{Ru} / \mathrm{CeO}_{2}$ catalysts for the transfer-allylation from tertiary homoallylic alcohols to aldehydes [42], the addition of aromatic $\mathrm{C}-\mathrm{H}$ bonds to vinylsilanes [44], and the direct arylation of aromatic $\mathrm{C}-\mathrm{H}$ bonds by chloroarenes [48]. These reactions had only been achieved by the use of homogeneous transition-metal complex catalysts so far, and therefore, the works in this account provided the first successful examples of solid-catalysts that achieved carbon-carbon bond formation via the activation of non-strained $\mathrm{C}-\mathrm{C}$ bonds or non-activated stable $\mathrm{C}-\mathrm{H}$ bonds. These results indicate the wide possibility of $\mathrm{Ru} / \mathrm{CeO}$ as an attractive, environmentally benign alternative to homogeneous ruthenium complex catalysts.

In addition, we showed that $\mathrm{CeO}_{2}$ powders of high surface areas can be 
prepared by the coagulation of ceria colloidal nanoparticles with suitable coagulants followed by calcination. The mobility of surface oxygen of the $\mathrm{CeO}_{2}$ support as well as the dispersion state of ruthenium species are found to be key factors for the oxidation activity of $\mathrm{Ru} / \mathrm{CeO}_{2}$ [50]. Furtheremore, the pore structures of the thus-obtained $\mathrm{CeO}_{2}$ powders are controlled by the selection of the coagulant, and the ruthenium catalyst supported on $\mathrm{CeO}_{2}$ possessing meso- and/or macro-pores shows high activity for the oxidation of benzyl alcohol $[58,59]$.

For further development of $\mathrm{Ru} / \mathrm{CeO}_{2}$ catalysts having excellent activities for a greater diversity of the reactions, precise control of the surface ruthenium species, migration ability of surface oxygen, and pore structure would be required. Detailed investigation on the control of the properties of $\mathrm{CeO}_{2}$ shown in the latter parts clearly indicates the possibility for further development of the $\mathrm{CeO}_{2}$-based catalysis, for example, more effective $\mathrm{Ru} / \mathrm{CeO}_{2}$ catalysts for a wide range of organic transformations including $\mathrm{C}-\mathrm{C}$ and/or $\mathrm{C}-\mathrm{H}$ bond activation.

\section{Acknowledgements}

A part of this work was supported by a Grant-in-Aid for Scientific Research (No. 21360393 and 21651039) from the Ministry of Education, Culture, Sports, Science and 
Technology, Japan. 


\section{References}

1. Trovarelli A, Catalysis by ceria and related materials, in: Hutchings GJ (Ed.),

Catalytic Science Series, Imperial College Press., London, 2002.

2. Le Normand F, Hilaire L, Kili K, Krill G, Maire G (1988) J Phys Chem 92:2561.

3. Kašpar J, Fornasiero P, Graziani M (1999) Catal Today 50:285.

4. Bera P, Patil KC, Jayaram V, Subbanna GN, Hegde MS (2000) J Catal 196:293.

5. Bedrane S, Descorme C, Duprez D (2002) Catal Today 75:401.

6. Boaro M, Vicario M, de Leitenburg C, Dolcetti G, Trovarelli A (2003) Catal Today $77: 407$.

7. Lee JH (2003) J Mater Sci 38:4247.

8. Li R, Yabe S, Yamashita M, Momose S, Yoshida S, Yin S, Sato T (2002) Solid State Ionics 151:235.

9. Steele BCH (1999) Nature 400:619;

10. Steele BCH, Heinzel A (2001) Nature 414:345.

11. Yao HC, Yao YFY (1984) J Catal 86:254.

12. Gandhi HS, Graham GW, McCabe RW (2003) J Catal 216:433.

13. Christou SY, Costa CN, Efstathiou AM (2004) Top Catal 30:325.

14. Seo HJ, Yu EY (2005) J Ind Eng Chem 11:681. 
15. Imamura S, Tadani J, Saito Y, Okamoto Y, Jindai H, Kaito C (2000) Appl Catal A 201:121.

16. Bera P, Gayen A, Hegde MS, Lalla NP, Spadaro L, Frusteri F, Arena F (2003) J Phys Chem B 107:6122.

17. Imamura S, Higashihara T, Saito Y, Aritani H, Kanai H, Matsumura Y, Tsuda N (1999) Catal Today 50:369.

18. Imamura S, Denpo K, Kanai H, Yamane H, Saito Y, Utani K, Matsumura Y (2001) J Jpn Petrol Inst 44:293.

19. Carrettin S, Guzman J, Corma A (2005) Angew Chem Int Ed 44:2242.

20. Corma A, González-Arellano C, Iglesias M, Sánchez F (2007) Angew Chem Int Ed 46:7820.

21. Hosokawa S, Nogawa S, Taniguchi M, Utani K, Kanai H, Imamura S (2005) Appl Catal A Gen 288:67.

22. Vocanson F, Guo YP, Namy JL, Kagan HB (1998) Synth Comm 28:2577.

23. Ji H, Mizugaki T, Ebitani K, Kaneda K (2002) Tetrahedron Lett 43:7179.

24. Ebitani K, Ji H, Mizugaki T, Kaneda K (2004) J Mol Catal A 212:161.

25. Barbier J Jr., Delanoë F, Jabouille F, Duprez D, Blanchard G, Isnard P (1998) J Catal $177: 378$ 
26. Imamura S, Fukuda I, Ishida S (1988) Ind Eng Chem Res 27:718.

27. Izumi Y, Iwata Y, Aika K (1996) J Phys Chem 100:9421.

28. Mitsui T, Matsui T, Kikuchi R, Eguchi K (2009) Top Catal 52:464

29. Hosokawa S, Fujinami Y, Kanai H (2005) J Mol Catal A Chemical 240:49.

30. Singh P, Hegde MS (2009) Chem Mater 21:3337.

31. Murahashi S (Eds.) (2004) Ruthenium in Organic Synthesis, Wiley-VCH, Weinheim.

32. Noyori R (2003) Adv Syn Catal 345:15.

33. Grubbs RH (2004) Tetrahedron 60:7117.

34. Murai S, Kakiuchi F, Sekine S, Tanaka Y, Kamatani A, Sonoda M, Chatani N (1993) Nature 366:529.

35. Martinez R, Simon MO, Chevalier R, Pautigny C, Genet JP, Darses S, J Am Chem Soc (2009) 131:7887.

36. Kondo T, Mitsudo T (2005) Chem Lett 34:1462.

37. Mitsudo T, Suzuki T, Zhang SW, Imai D, Fujita K, Manabe T, Shiotsuki M, Watanabe Y, Wada K, Kondo T (1999) J Am Chem Soc 121:1839.

38. Sheldon RA, Downing RS (1999) Appl Catal A Gen 189:163.

39. Kaneda K (2007) Synlett 999. 
40. Kondo T, Kodoi K, Nishinaga E, Okada T, Morisaki Y, Watanabe Y, Mitsudo T (1998) J Am Chem Soc 120:5587.

41. Hayashi S, Hirano K, Yorimitsu H, Oshima K (2006) J Am Chem Soc 128:2210.

42. Miura H, Wada K, Hosokawa S, Sai M, Kondo T, Inoue M (2009) Chem Commun 4112.

43. Lee CLK, Lee CHA, Tan KT, Loh TP (2004) Org Lett 6:1281 and references therein.

44. Miura H, Wada K, Hosokawa S, Inoue M (2010) ChemCatChem accepted.

45. Oi S, Fukita, S, Hirata N, Watanuki N, Miyano S, Inoue Y (2001) Org Lett 3:2579.

46. Ackermann L (2005) Org Lett 7:3123.

47. Özdemir I, Demir S, Çetinkaya B, Gourlaouen C, Maseras F, Bruneau C, Dixneuf PH (2008) J Am Chem Soc 130:1156.

48. Miura H, Wada K, Hosokawa S, Inoue M (2010) Chem Eur J 16:4186.

49. Guglielminotti E, Boccuzzi F, Manzoli M, Pinna F, Scarpa M (2000) J Catal 192:149.

50. Hosokawa S, Hayashi Y, Imamura S, Wada K, Inoue M (2009) Catal Lett 129:394.

51. Hosokawa S, Kanai H, Utani K, Taniguchi Y, Saito Y, Imamura S (2003) Appl Catal B Environ 45:181. 
52. Yamamoto S, Kakihana M, Kato S (2000) J Alloys Compd 297:81.

53. Masui T, Fujiwara K, Machida K, Adachi G, Sakata T, Mori H (1997) Chem Mater 9:2197.

54. Hirano M, Kato E (1996) J Am Ceram Soc 79:777.

55. Inoue M, Kimura M, Inui T (1999) Chem Commun 975.

56. Kobayashi T, Hosokawa S, Iwamoto S, Inoue M (2006) J Am Ceram Soc 89:1205.

57. Kobayashi T, Iwamoto S, Inoue M (2006) J Alloys Compd 408-412:1149.

58. Hayashi Y, Hosokawa S, Imamura S, Inoue M (2007) J Ceram Soc Jpn 115:592.

59. Hayashi Y, Hosokawa S, Inoue M (2010) Microporous Mesoporous Mater 128:115.

60. Cotton FA, Wilkinson G (1966) Advanced Inorganic Chemistry: A Comprehensive Text, second ed., John Wiley \& Sons, New York, pp. 1067-1068.

\section{Captions for Figures and Schemes}

Scheme 1 Effect of $\mathrm{PPh}_{3}$-modification of $\mathrm{Ru} / \mathrm{CeO}_{2}$ catalyst in $\mathrm{H}_{2}$ towards addition of a $\mathrm{C}-\mathrm{H}$ bond of $\alpha$-tetralone to to triethoxyvinylsilane [44] 
Figure 1 TPR profiles of $\mathrm{Ru} / \mathrm{CeO}_{2}-\mathrm{B}, \mathrm{RuO}_{2}-\alpha-\mathrm{Al}_{2} \mathrm{O}_{3}\left(\mathrm{RuO}_{2}\right.$ was physically mixed with $\alpha-\mathrm{Al}_{2} \mathrm{O}_{3}$ ), and $\mathrm{CeO}_{2}-\mathrm{B}[50]$. Heating rate $5{ }^{\circ} \mathrm{C} \mathrm{min}^{-1}$, catalyst loading $0.10 \mathrm{~g}, 2.0 \%$ of $\mathrm{H}_{2}$ in $\operatorname{Ar}\left(30 \mathrm{~mL} \mathrm{~min}^{-1}\right)$. Expanded profiles in the temperature range of $50-150{ }^{\circ} \mathrm{C}$ are shown in b).

Figure 2 Repeated TPR profiles (lower) and the temperature diagram for the experiment (upper) [50].

Figure 3 Nitrogen adsorption/desorption isotherms of the selected $\mathrm{CeO}_{2}$ powders coagulated with aqueous solutions (1 M) of (a) $\mathrm{NaHCO}_{3}$, (b) $\mathrm{NaOH}$, (c) $\mathrm{Na}_{2} \mathrm{CO}_{3}$, (d) $\left(\mathrm{NH}_{4}\right)_{2} \mathrm{CO}_{3}$, (e) $\mathrm{NH}_{4} \mathrm{HCO}_{3}$, and (f) $\mathrm{NH}_{4} \mathrm{OH}$, calcined at $300{ }^{\circ} \mathrm{C}$ [58].

Figure 4 Nitrogen adsorption/desorption isotherms of the selected $\mathrm{CeO}_{2}$ powders coagulated with (a) $1 \mathrm{M}$, (b) $5 \mathrm{M}$, and (c) $10 \mathrm{M}$ aqueous $\mathrm{NaOH}$ solutions, followed by calcination at $300{ }^{\circ} \mathrm{C}[59]$. 
Table 1 Effect of ruthenium catalysts for allyl transfer reaction [42]

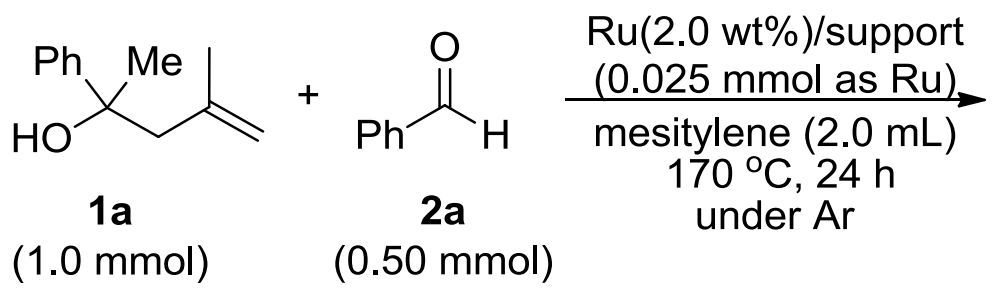<smiles>CC(=O)c1ccccc1</smiles>

3<smiles>CC(C)CC(=O)c1ccccc1</smiles>

$4 a$

\begin{tabular}{llc}
\hline Entry & Catalyst & Yield $[\%]^{\mathrm{a}, \mathrm{b}}$ \\
\hline 1 & $\mathrm{CeO}_{2}$ & 0 \\
2 & $\mathrm{Ru} / \mathrm{CeO}_{2}$ & 69 \\
3 & $\mathrm{Ru} / \mathrm{SiO}_{2}$ & 0 \\
4 & $\mathrm{Ru} / \mathrm{Al}_{2} \mathrm{O}_{3}$ & 0 \\
5 & $\mathrm{Ru} / \mathrm{TiO}_{2}$ & $0^{\mathrm{c}}$ \\
6 & $\mathrm{Ru} / \mathrm{MgO}$ & 0 \\
7 & $\mathrm{Ru}_{3}(\mathrm{CO})_{12}$ & 15 \\
\hline
\end{tabular}

${ }^{a}$ Determined by GLC.

${ }^{\mathrm{b}}$ Yield based on $\mathbf{2 a}$.

${ }^{c}$ Acidic $\mathrm{TiO}_{2}$ and $\mathrm{Ru} / \mathrm{TiO}_{2}$ catalysts gave $\mathbf{5 a}$ via intramolecular Friedel-Crafts reaction of $\mathbf{1 a}$. 
Table 2 Scope of substrates for $\mathrm{Ru} / \mathrm{CeO}_{2}$-catalyzed allyl transfer reaction [42]
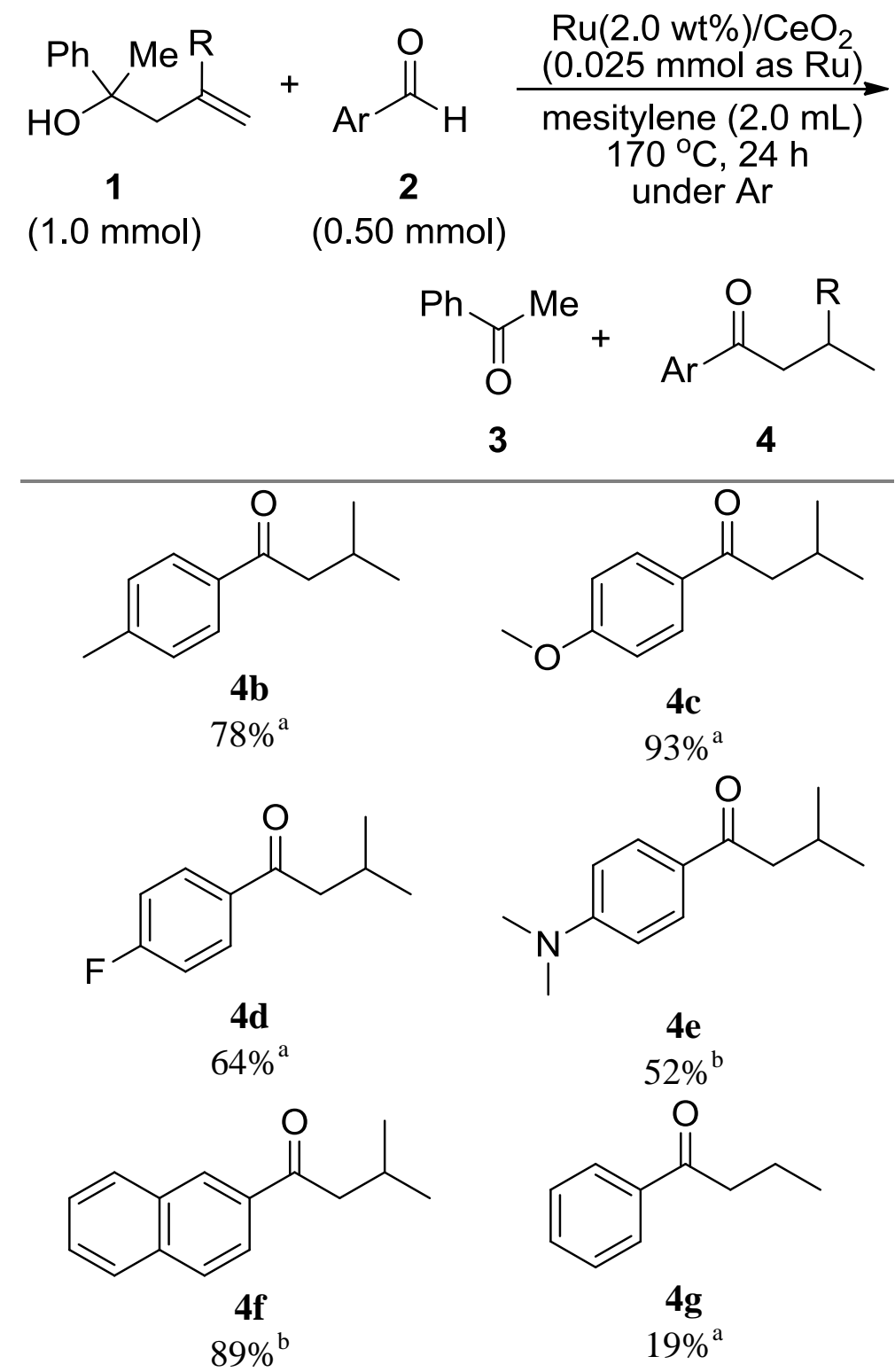

${ }^{a}$ Determined by GLC.

${ }^{\mathrm{b}}$ Isolated yields. 
Table 3 Effect of ruthenium catalysts for addition of a C-H bond of $\alpha$-tetralone to triethoxyvinylsilane [44]<smiles>CCO[SiH2]C=C[CH+]=C1CCCc2ccccc21</smiles>

$7 a$

$(1.0 \mathrm{mmol})$
$8 \mathbf{a}$ $(2.0 \mathrm{mmol})$
$\mathrm{Ru}(2.0 \mathrm{wt} \%) / \mathrm{CeO}_{2}$ (0.025 mmol as Ru) $\mathrm{PPh}_{3}(0.10 \mathrm{mmol})$

Mesitylene $(2.0 \mathrm{~mL})$ $170^{\circ} \mathrm{C}, 24 \mathrm{~h}$ under $\mathrm{Ar}$<smiles>CCO[SiH2]CCc1cccc2c1C(=O)CCC2</smiles>

9a

\begin{tabular}{llc}
\hline Entry & Catalyst & ${\text { Yield }[\%]^{\mathrm{a}, \mathrm{b}}}^{\mathrm{c}, \mathrm{d}}$ \\
\hline 1 & $\mathrm{Ru} / \mathrm{CeO}_{2}$ & $0^{\mathrm{c}}$ \\
2 & $\mathrm{Ru} / \mathrm{CeO}_{2}$ & 99 \\
3 & $\mathrm{Ru} / \mathrm{CeO}_{2}$ & 99 \\
4 & $\mathrm{Ru} / \mathrm{ZrO}_{2}$ & 0 \\
5 & $\mathrm{Ru} / \mathrm{SiO}_{2}$ & 0 \\
6 & $\mathrm{Ru} / \mathrm{Al}_{2} \mathrm{O}_{3}$ & 0 \\
7 & $\mathrm{Ru} / \mathrm{TiO}_{2}$ & 0 \\
8 & $\mathrm{Ru} / \mathrm{MgO}$ & 0 \\
\hline
\end{tabular}

${ }^{a}$ Determined by GLC.

${ }^{\mathrm{b}}$ Yield based on $\mathbf{7 a}$.

${ }^{\mathrm{c}}$ Reaction time $6 \mathrm{~h}$.

${ }^{d}$ Without $\mathrm{PPh}_{3}$. 
Table 4 Scope of substrates for $\mathrm{Ru} / \mathrm{CeO}_{2}$-catalyzed addition of $\mathrm{C}-\mathrm{H}$ bonds of aromatic ketones to vinylsilanes ${ }^{\mathrm{a}}$ [44]

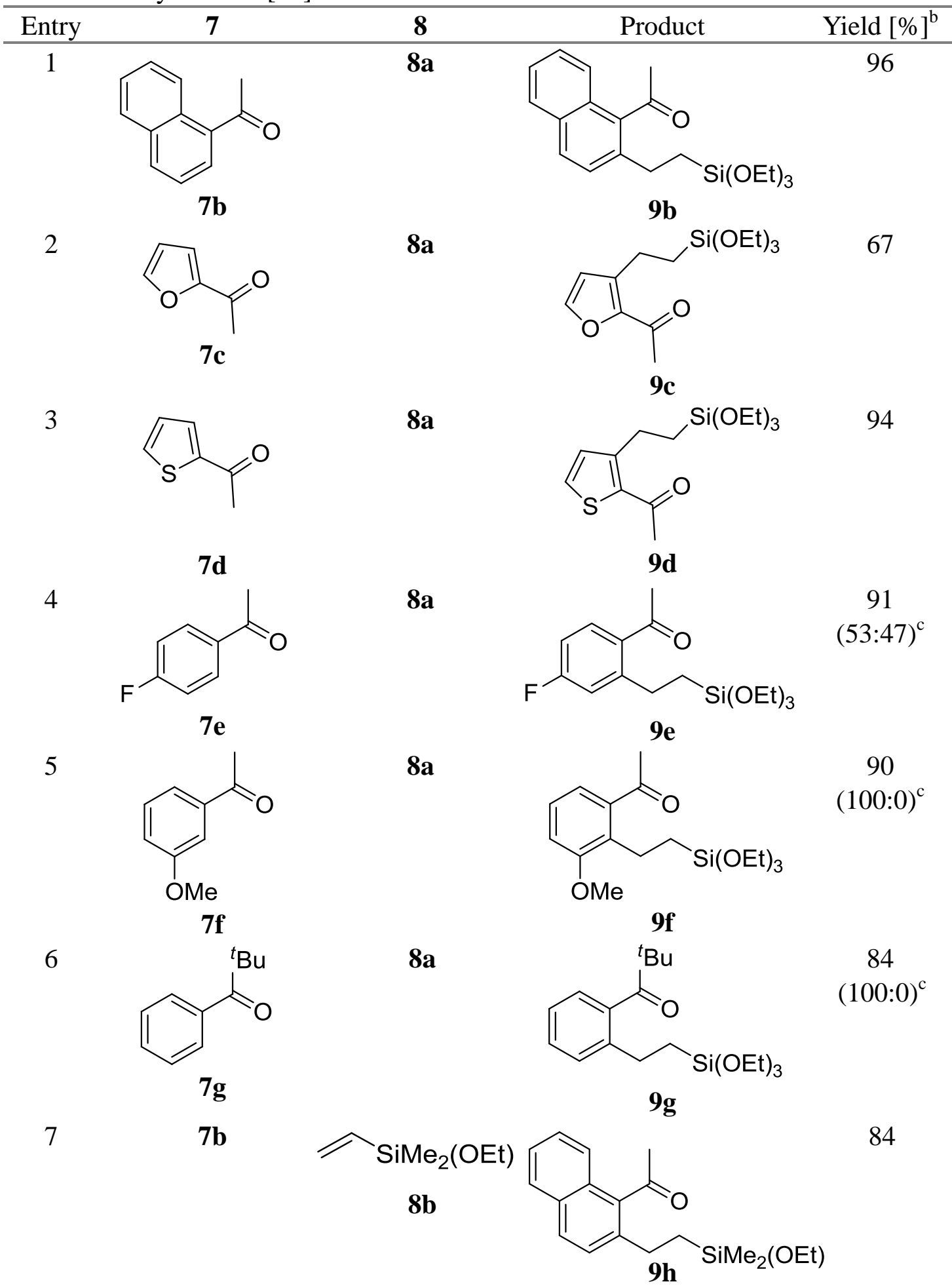

\footnotetext{
${ }^{a}$ Reaction conditions: 7, $1.0 \mathrm{mmol} ; \mathbf{8}, 2.0 \mathrm{mmol} ; \mathrm{Ru} / \mathrm{CeO}_{2}, 0.025 \mathrm{mmol}$ as $\mathrm{Ru}$ atom; mesitylene, $2.0 \mathrm{~mL} ; 170{ }^{\circ} \mathrm{C} ; 24 \mathrm{~h}$.

${ }^{\mathrm{b}}$ Isolated yields.

${ }^{c}$ The percentages of mono- and di-substituted products are given in parentheses.
} 
Table 5 Scope of substrates for $\mathrm{Ru} / \mathrm{ZrO}_{2}$-catalyzed direct arylation of benzo[ $h]$ quinoline with aryl chlorides [48]

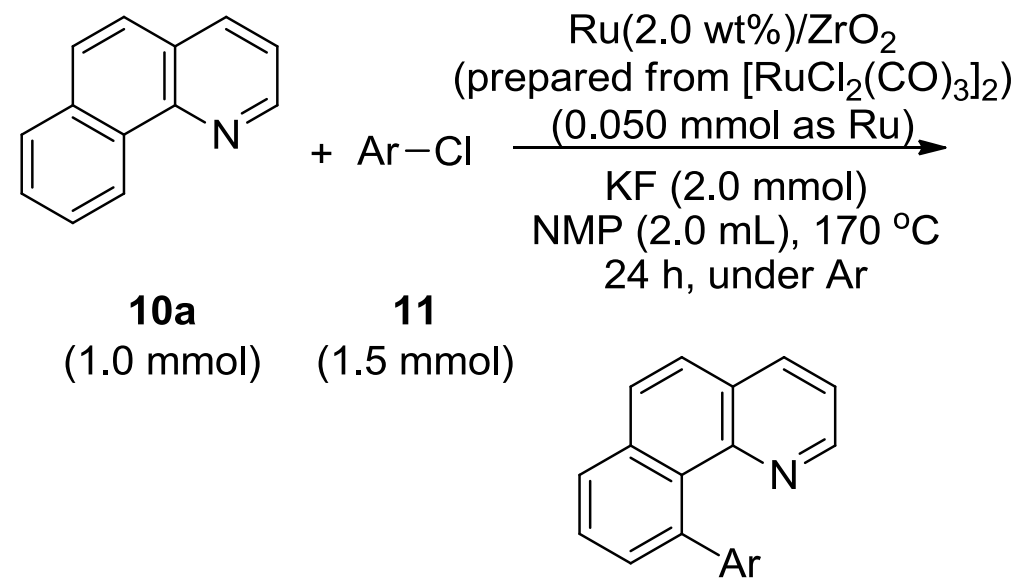

12

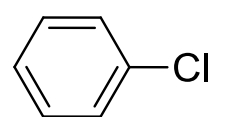

11a

$94 \%^{\mathrm{a}}$<smiles>Cc1cccc(Cl)c1</smiles>

11c

$60 \%$<smiles>Fc1ccc(Cl)cc1</smiles>

$11 \mathrm{e}$

$69 \%$<smiles>COc1ccc(Cl)cc1</smiles>

$11 \mathrm{~g}$

$0 \%$

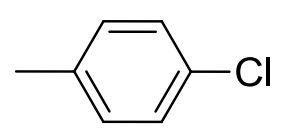

11b

$72 \%$<smiles>Cc1ccccc1Cl</smiles>

11d

$62 \%$<smiles>FC(F)(F)c1ccc(Cl)cc1</smiles>

$11 f$

$92 \%$<smiles>COc1ccc(Cl)cc1</smiles>

$11 \mathrm{~g}$

${ }^{\mathrm{a}}$ Reaction for $18 \mathrm{~h}$.

${ }^{\mathrm{b}}$ With $0.10 \mathrm{mmol}$ of $\mathrm{PPh}_{3}$. 
Table 6 Scope of substrates for $\mathrm{PPh}_{3}$-modified

$\mathrm{Ru} / \mathrm{CeO}_{2}$-catalyzed direct arylation of benzo[ $\left.h\right]$ quinoline with aryl halides [48]

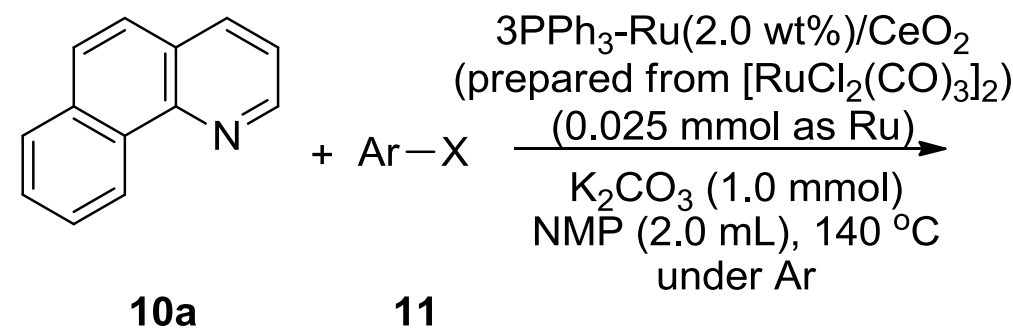

$(0.50 \mathrm{mmol}) \quad(0.75 \mathrm{mmol})$<smiles>Brc1cccc2ccc3cccnc3c12</smiles>

12

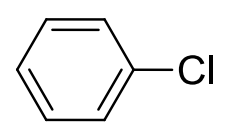

$11 a$

$94 \%(6 \mathrm{~h})$<smiles>FC(F)(F)c1ccc(Cl)cc1</smiles>

$11 f$ $86 \%(12 \mathrm{~h})$<smiles>Brc1ccccc1</smiles>

$11 \mathrm{~h}$

$96 \%\left(120^{\circ} \mathrm{C}, 2 \mathrm{~h}\right)$<smiles>COC(=O)c1ccc(Cl)cc1</smiles>

$11 \mathbf{j}$

91\% (5 h)<smiles>Clc1cccs1</smiles>

111<smiles>Cc1ccc(Cl)cc1</smiles>

11b

$96 \%(6 \mathrm{~h})$<smiles>COc1ccc(Cl)cc1</smiles>

$11 \mathrm{~g}$

96\% (12 h)<smiles>CC(=O)c1ccc(Cl)cc1</smiles>

$11 i$

95\% (3 h)<smiles>Clc1ccc2ccccc2c1</smiles>

$11 k$

98\% (5 h)<smiles>Clc1ccccn1</smiles>

$11 \mathrm{~m}$

$53 \%(6 \mathrm{~h})$ 
Table 7 Scope of substrates for $\mathrm{PPh}_{3}$-modified $\mathrm{Ru} / \mathrm{CeO}_{2}$-catalyzed direct arylation with 4-chloroacetophenone [48]

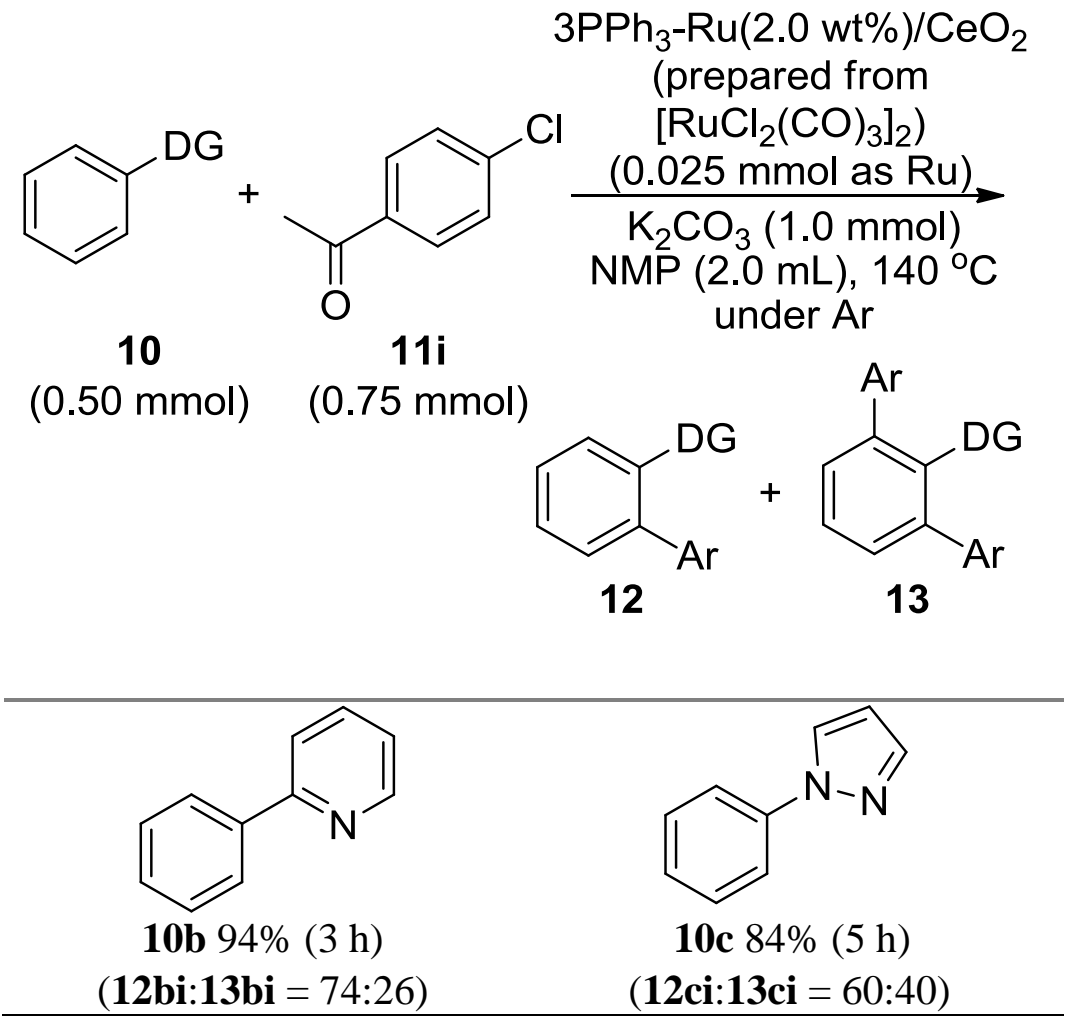


Table 8 Preparation, properties and catalytic activity of $\mathrm{Ru}(2.0 \mathrm{wt} \%) / \mathrm{CeO}_{2}$ toward the liquid-phase oxidation of benzyl alcohol [50]

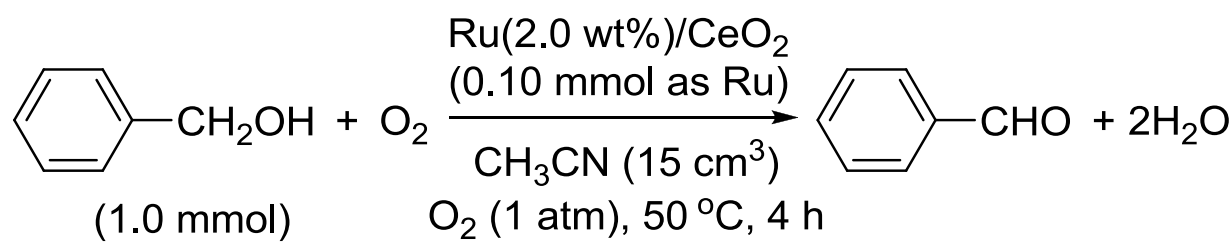

\begin{tabular}{llllll}
\hline Entry & Catalyst & Ce source & $\begin{array}{l}\text { BET } \\
\text { surface } \\
\text { area } \\
{\left[\mathrm{m}^{2} \mathrm{~g}^{-1}\right]}\end{array}$ & $\begin{array}{l}\mathrm{H}_{2} \text { consump- } \\
\text { tion } \\
{\left[\mathrm{mmol} \mathrm{g}^{-1}\right]^{\mathrm{a}}}\end{array}$ & $\begin{array}{l}\text { Benzaldehyde } \\
\text { yield [\%] }\end{array}$ \\
\hline 1 & $\mathrm{Ru} / \mathrm{CeO}_{2}-\mathrm{A}$ & $\begin{array}{l}\text { ceria colloidal } \\
\text { nanoparticles } \\
\mathrm{Ce}\left(\mathrm{NO}_{3}\right)_{3} \cdot 6 \mathrm{H}_{2} \mathrm{O}\end{array}$ & 135 & 0.87 & 60 \\
2 & $\mathrm{Ru} / \mathrm{CeO}_{2}-\mathrm{B}$ & 0.72 & 36 \\
\hline
\end{tabular}

${ }^{\mathrm{a}}$ Estimated by TPR experiment. 
Table 9 Redox properties of $\mathrm{CeO}_{2}$ powders prepared by different methods followed by calcination at $400{ }^{\circ} \mathrm{C}[50]$

\begin{tabular}{|c|c|c|c|c|c|}
\hline \multirow{2}{*}{ Entry } & \multirow{2}{*}{$\mathrm{CeO}_{2}$} & \multirow{2}{*}{ Ce source } & \multirow{2}{*}{$\begin{array}{l}\text { BET } \\
\text { surface area } \\
{\left[\mathrm{m}^{2} \mathrm{~g}^{-1}\right]}\end{array}$} & \multicolumn{2}{|c|}{$\mathrm{H}_{2}$ consumption $\left[\mathrm{mmol} \mathrm{g}^{-1}\right]$} \\
\hline & & & & $1^{\text {st }}$ run & $2^{\text {nd }}$ run \\
\hline 1 & $\mathrm{CeO}_{2}-\mathrm{A}$ & $\begin{array}{l}\text { ceria colloidal } \\
\text { nanoparticles }\end{array}$ & 103 & $0.36(\mathrm{~L})^{\mathrm{a}}$ & $\begin{array}{l}0.29(\mathrm{~L})^{\mathrm{a}}(81 \%)^{\mathrm{b}} \\
0.54(\mathrm{H})^{\mathrm{c}}\end{array}$ \\
\hline 2 & $\mathrm{CeO}_{2}-\mathrm{B}$ & $\mathrm{Ce}\left(\mathrm{NO}_{3}\right)_{3} \cdot 6 \mathrm{H}_{2} \mathrm{O}$ & 139 & $0.41(\mathrm{~L})^{\mathrm{a}}$ & $\begin{array}{l}0.25(\mathrm{~L})^{\mathrm{a}}(61 \%)^{\mathrm{b}} \\
0.43(\mathrm{H})^{\mathrm{c}}\end{array}$ \\
\hline
\end{tabular}

${ }^{a}$ Estimated from the area of low temperature peak $\left(<500{ }^{\circ} \mathrm{C}\right)$ of the $\mathrm{H}_{2}$-TPR study.

${ }^{\mathrm{b}}$ Percentage of the area of low temperature peak in the $2^{\text {nd }}$ run versus that of $1^{\text {st }}$ run.

${ }^{c}$ Estimated from the area of high temperature peak $\left(>500{ }^{\circ} \mathrm{C}\right)$ of the $\mathrm{H}_{2}$-TPR study. 
Table 10 Characterization of the $\mathrm{CeO}_{2}$ powders coagulated by various bases followed by calcination ${ }^{\mathrm{a}}$ and Catalytic activity of $\mathrm{Ru}(2.0 \mathrm{wt} \%) / \mathrm{CeO}_{2}$ toward the liquid-phase oxidation of benzyl alcohol at $50{ }^{\circ} \mathrm{C}$ for $4 \mathrm{~h}$ [58]

\begin{tabular}{llllll}
\hline Entry & Coagulant & $\begin{array}{l}\text { Crystallite } \\
\text { size }[\mathrm{nm}]\end{array}$ & $\begin{array}{l}\text { Total } \\
\text { surface area } \\
{\left[\mathrm{m}^{2} \mathrm{~g}^{-1}\right]^{\mathrm{b}}}\end{array}$ & $\begin{array}{l}\text { Benzyl } \\
\text { alcohol } \\
\text { conversion } \\
{[\%]^{\mathrm{c}}}\end{array}$ & $\begin{array}{l}\text { Benzaldehy } \\
\text { de yield } \\
{[\%]^{\mathrm{d}}}\end{array}$ \\
\hline 1 & $\mathrm{NaOH}$ & 5.2 & 132 & 42.3 & 37.1 \\
2 & $\mathrm{NH}_{4} \mathrm{OH}$ & 5.2 & 111 & 32.5 & 28.4 \\
3 & $\mathrm{Na}_{2} \mathrm{CO}_{3}$ & 4.6 & 67 & 16.8 & 8.6 \\
4 & $\left(\mathrm{NH}_{4}\right)_{2} \mathrm{CO}_{3}$ & 4.8 & 152 & 79.6 & 58.0 \\
5 & $\mathrm{NaHCO}_{3}$ & 4.2 & 79 & 81.2 & 58.3 \\
6 & $\mathrm{NH}_{4} \mathrm{HCO}_{3}$ & 5.2 & 92 & 81.4 & 57.8 \\
7 & $\mathrm{NaOH}^{\mathrm{b}}$ & - & - & 53.0 & 35.5 \\
\hline
\end{tabular}

${ }^{a}$ At $300{ }^{\circ} \mathrm{C}$ for $3 \mathrm{~h}$ in air.

${ }^{\mathrm{b}}$ Estimated by the $V$ - $t$ plot.

${ }^{c}$ Determined by GLC.

${ }^{\mathrm{d}}$ Prepared by coprecipitation method from $\mathrm{Ce}\left(\mathrm{NO}_{3}\right)_{3} \cdot 6 \mathrm{H}_{2} \mathrm{O}$. 
Table 11 Pore structures of the $\mathrm{CeO}_{2}$ powders prepared by coagulation or precipitation with $\mathrm{NaOH}$ solutions with various concentrations followed by the calcination ${ }^{\mathrm{a}}$ [59]

\begin{tabular}{llllll}
\hline Entry & Precursor & $\begin{array}{l}\mathrm{NaOH} \\
{[\mathrm{M}]}\end{array}$ & $\begin{array}{l}\text { Total pore } \\
\text { volume } \\
{\left[\mathrm{cm}^{3} \mathrm{~g}^{-1}\right]}\end{array}$ & $\begin{array}{l}\text { BET surface } \\
\text { area }\left[\mathrm{m}^{2} \mathrm{~g}^{-1}\right]\end{array}$ & $\begin{array}{l}\text { Amount of Ce } \\
\text { ions dissolved } \\
{\left[\mathrm{ppm}(\%)^{\mathrm{b}}\right]}\end{array}$ \\
\hline 1 & ceria colloidal & 1 & 0.097 & 122 & $0.82(0.008)$ \\
2 & nanoparticles & 5 & 0.135 & 123 & $-{ }^{\mathrm{c}}$ \\
3 & & 10 & 0.184 & 124 & $16.00(0.147)$ \\
\hdashline 4 & & 1 & 0.267 & 167 & $0.64(0.006)$ \\
5 & $\mathrm{Ce}\left(\mathrm{NO}_{3}\right)_{3} \cdot 6 \mathrm{H}_{2} \mathrm{O}$ & 5 & 0.287 & 167 & $-{ }^{\mathrm{c}}$ \\
6 & & 10 & 0.280 & 166 & $0.11(0.001)$ \\
\hline
\end{tabular}

${ }^{\mathrm{a}}$ Calcined at $300^{\circ} \mathrm{C}$ for $3 \mathrm{~h}$ in air.

${ }^{\mathrm{b}}$ Percentages of cerium ions dissolved per $\mathrm{CeO}_{2}$ samples $(3.5 \mathrm{~g})$ during the coagulation.

${ }^{\mathrm{c}}$ Not measured. 

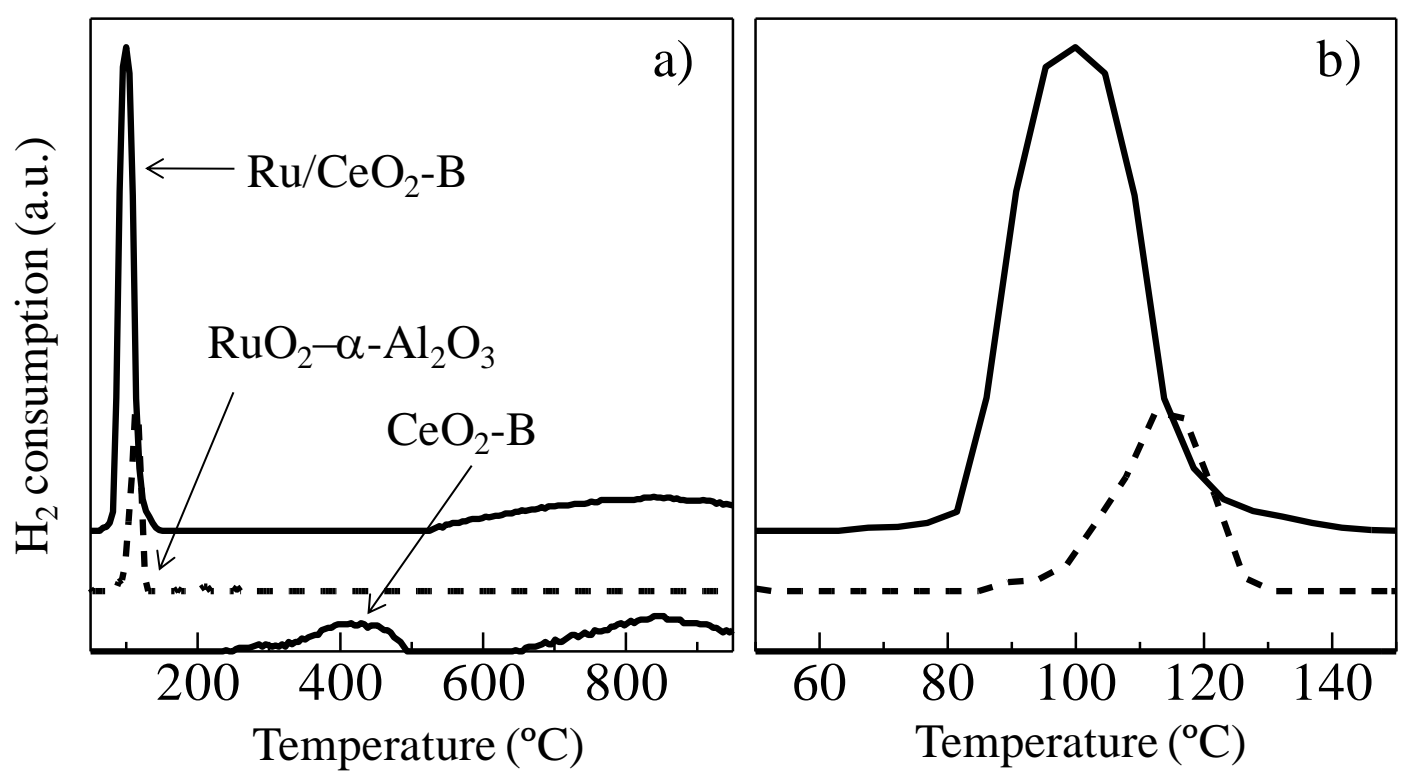

Figure 1 TPR profiles of $\mathrm{Ru} / \mathrm{CeO}_{2}-\mathrm{B}, \mathrm{RuO}_{2}-\alpha-\mathrm{Al}_{2} \mathrm{O}_{3}\left(\mathrm{RuO}_{2}\right.$ was physically mixed with $\alpha-\mathrm{Al}_{2} \mathrm{O}_{3}$ ), and $\mathrm{CeO}_{2}-\mathrm{B}$ [50]. Heating rate $5{ }^{\circ} \mathrm{C} \mathrm{min}^{-1}$, catalyst loading $0.10 \mathrm{~g}, 2.0 \%$ of $\mathrm{H}_{2}$ in $\operatorname{Ar}\left(30 \mathrm{~mL} \mathrm{~min}^{-1}\right)$. Spectra b) enlarged spectra a) from 50 to $150{ }^{\circ} \mathrm{C}$. 


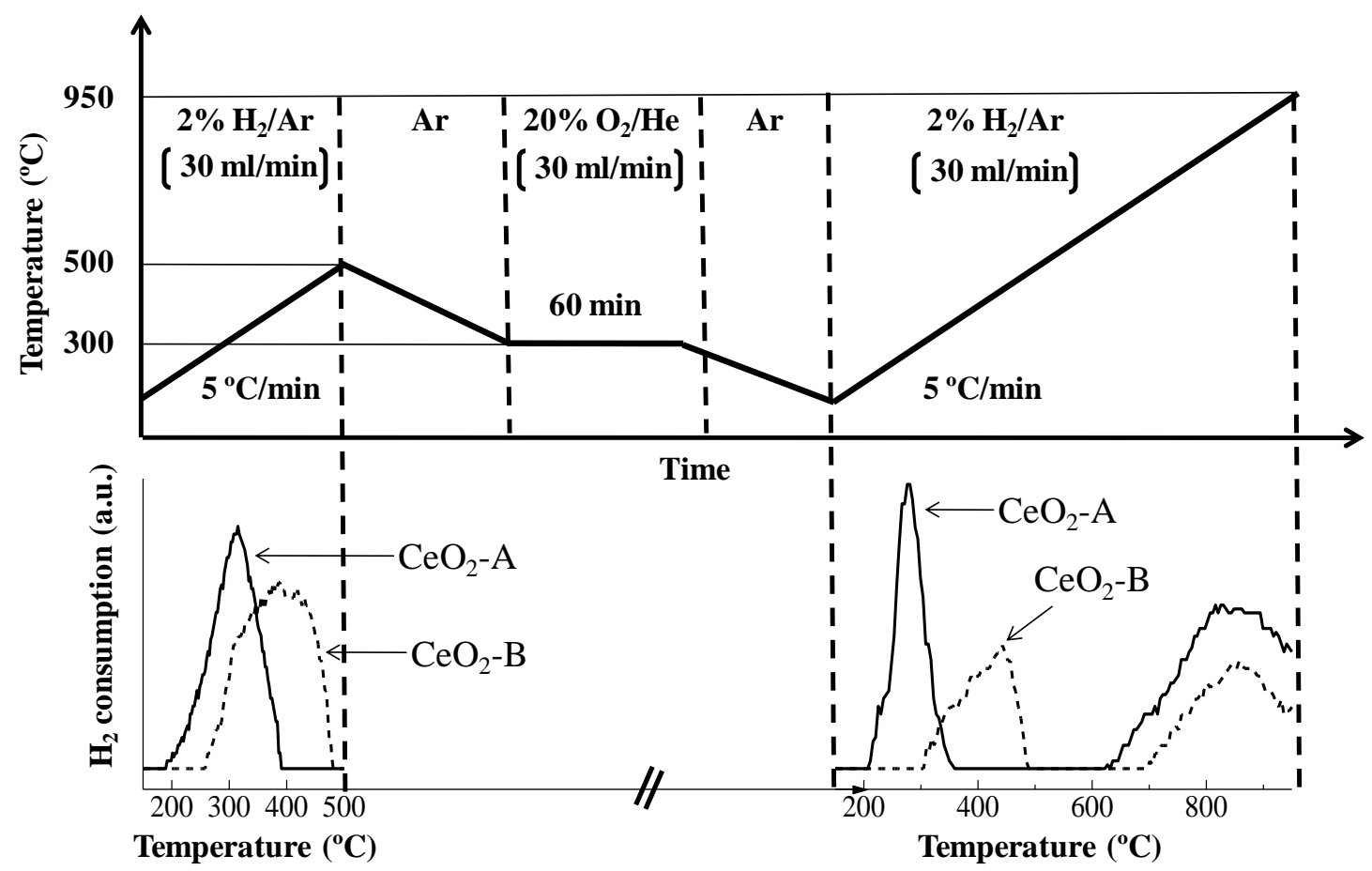

Figure 2 The temperature diagram for the repeated TPR experiments [50]. 


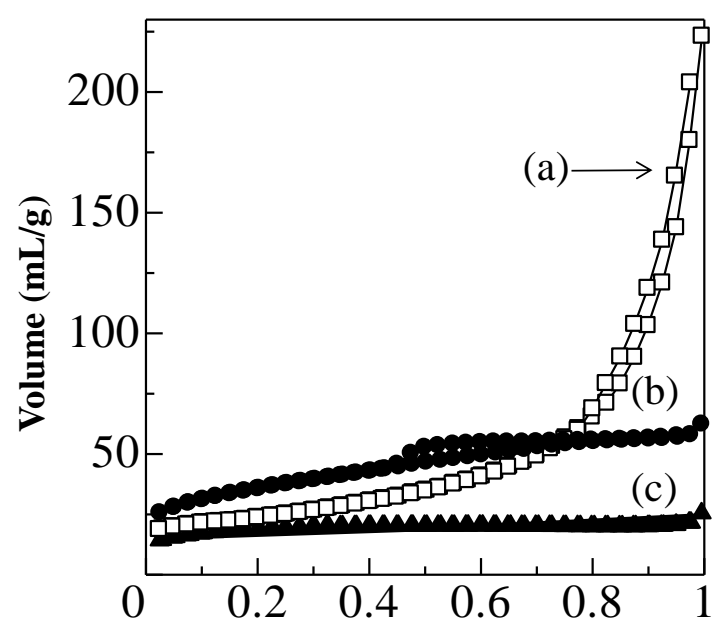

Relative Pressure, $P / P_{0}$

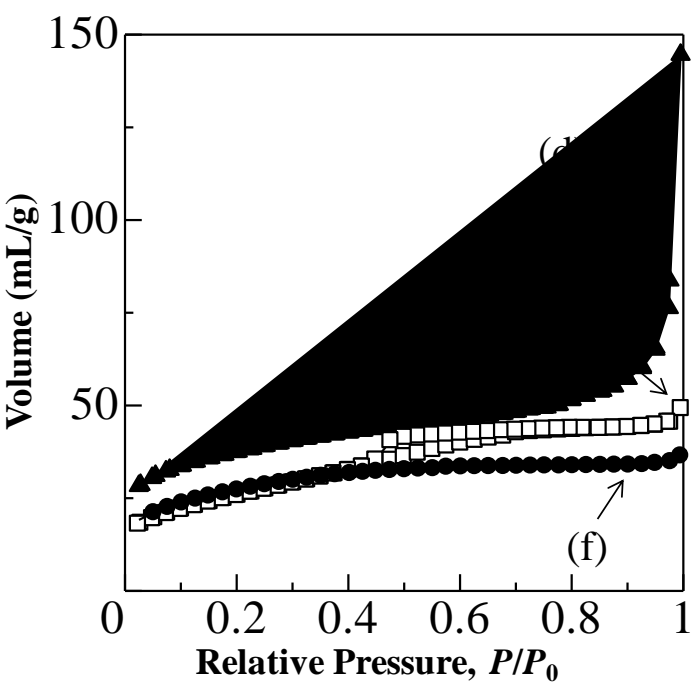

Figure 3 Nitrogen adsorption/desorption isotherms of the selected $\mathrm{CeO}_{2}$ powders coagulated with aqueous solutions ( $1 \mathrm{M}$ ) of (a) $\mathrm{NaHCO}_{3}$, (b) $\mathrm{NaOH}$, (c) $\mathrm{Na}_{2} \mathrm{CO}_{3}$, (d) $\left(\mathrm{NH}_{4}\right)_{2} \mathrm{CO}_{3}$, (e) $\mathrm{NH}_{4} \mathrm{HCO}_{3}$, and (f) $\mathrm{NH}_{4} \mathrm{OH}$, calcined at $300{ }^{\circ} \mathrm{C}$ [58]. 


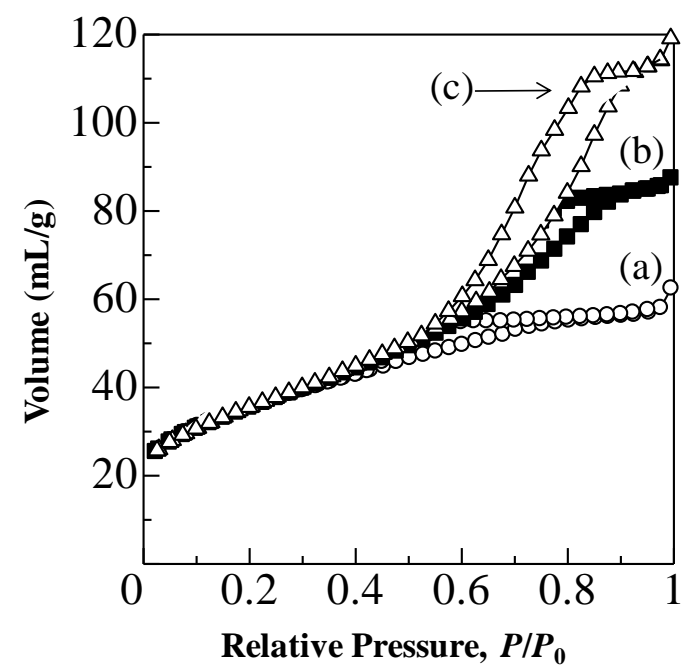

Figure 4 Nitrogen adsorption/desorption isotherms of the selected $\mathrm{CeO}_{2}$ powders coagulated with (a) $1 \mathrm{M}$, (b) $5 \mathrm{M}$, and (c) $10 \mathrm{M}$ aqueous $\mathrm{NaOH}$ solutions, followed by the calcination at $300{ }^{\circ} \mathrm{C}$ [59]. 


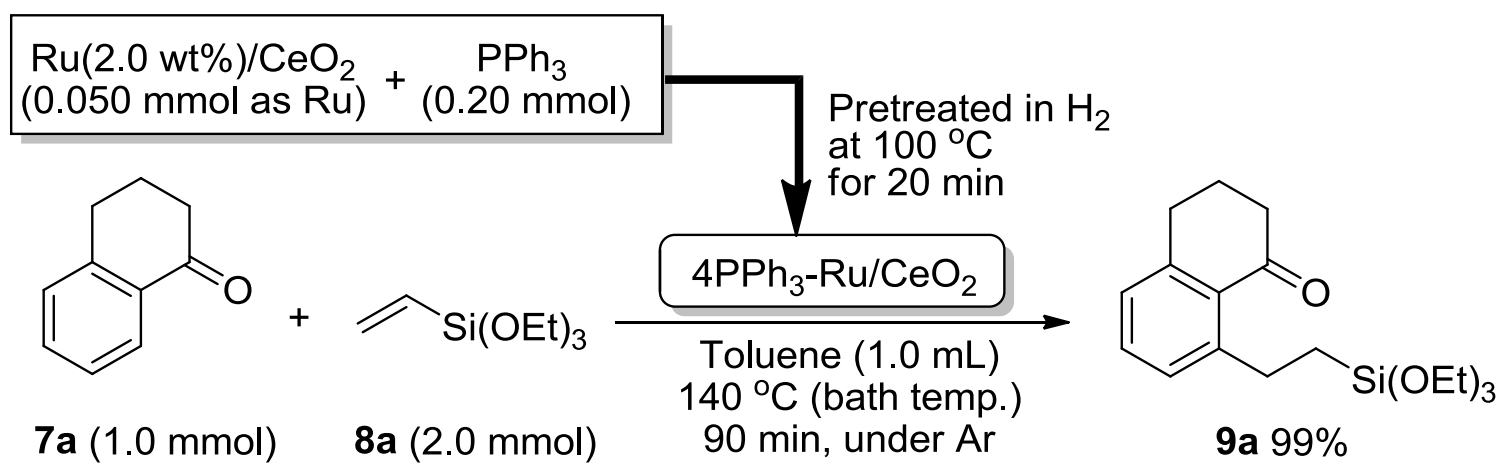

(Scheme1) 
(Eq. 1)<smiles>c1ccc2c(c1)ccc1cccnc12</smiles>

$10 a$ $(1.0 \mathrm{mmol})$<smiles>Clc1ccccc1</smiles>

$11 \mathrm{a}$ $(1.5 \mathrm{mmol})$
$\mathrm{Ru}(2.0$ wt $\%) / \mathrm{CeO}_{2}$

(prepared from $\mathrm{RuCl}_{3}$ )

$(0.050 \mathrm{mmol}$ as $\mathrm{Ru})$

$\mathrm{K}_{2} \mathrm{CO}_{3}(20 \mathrm{mmol})$

NMP $(2.0 \mathrm{~mL}), 170^{\circ} \mathrm{C}$ $18 \mathrm{~h}$, under $\mathrm{Ar}$<smiles>c1ccc(-c2cccc3ccc4cccnc4c23)cc1</smiles>

(1)

12a $89 \%$ 
(Structures of $\mathbf{5 a}$ and $\mathbf{6}$ )<smiles>CC1=CC(C)(C)c2ccccc21</smiles><smiles>C=C(C)CC(O)[AlH2]</smiles>

$5 a$ 